\title{
THE BOONE INDICATOR AS DETERMINANT OF CROATIAN INSURANCE MARKET SOUNDNESS
}

Tomislava Pavić Kramarić, Marko Miletić

\section{ABSTRACT}

This paper deals with the influence of competition on soundness of Croatian insurers using the Boone indicator when measuring competition. The authors analyse Croatian insurers that operated over the pre-EU accession period 2008 - 2012 as well as in the period 2013 - 2017, i.e. after the accession to the EU. Several firm-level, industry-level and macroeconomic variables are used in the research. The findings of the analysis are twofold. Specifically, the Boone indicator reveals the impact of competition on the performance of efficient insurers in post-EU accession period only accounting for the reallocation effects proving that efficient insurers make higher profits. Regarding the determinants of the insurers' soundness, premium to surplus ratio and inflation rate play significant role in pre - EU accession period whereas reinsurance and GDP growth rate are statistically significant after EU accession. Moreover, the competition increased in the years after the EU accession. Robustness check provides similar results.

Key words: soundness, Boone indicator, Croatian insurers

JEL: G22, G14, L25

\section{INTRODUCTION}

The insurance market in Croatia is constantly gaining importance over the last decades and in 2017 it accounted for $7.03 \%$ share in financial intermediaries' total assets (Croatian Insurance Bureau, Insurance Market in the Republic of Croatia 2017 - Key Facts). It also refers to the product diversification and services offered. This has been fuelled with the Croatian accession to the EU in July 2013, which is the reason why the authors have opted to investigate the competition measured with the Boone indicator and its effects on soundness of Croatian insurance market. This is done separately for the period prior to EU accession $(2008$ - 2012) as well as after the accession to the EU $(2013$ - 2017).

Specifically, Croatian insurance industry in this period offers especially interesting setting in which to investigate both competition and soundness. As part of the process of the continuous alignment with the acquis communautaire, amendments to the Insurance Act regulating to insurance activities in the Republic of Croatia were consistently made. This was done with

Tomislava Pavić Kramarić, PhD

Senior Lecturer

University of Split, University Department of

Professional Studies

E-mail: tpavic@oss.unist.hr

Marko Miletić, PhD

College Professor

University of Split, University Department of

Professional Studies

E-mail: mamiletic@oss.unist.hr 
the purpose to ensure total integration of the financial market of the Republic of Croatia into the single European market and to guarantee the uniform application of legal provisions in the Republic of Croatia and other EU member states. Therefore, prior to the accession, all the relevant directives had already been implemented in the Croatian legislation, and as of 1 July 2013, the day of Croatian accession to the EU, all EU regulations, including those relating to the insurance market, directly apply in the Republic of Croatia, as well. Croatia's accession to the EU was followed by the liberalisation of the insurance market and crossborder cooperation. This means that insurance companies with the headquarters in Croatia are allowed to participate in insurance markets of EU Member States either through the free provision of services or through the establishment of a branch. Under the same conditions, entities from other EU member states are allowed to participate in the Croatian insurance market. Therefore, having in mind Croatian accession to the EU in 2013, insurance directives were adopted into Croatian legislation and implemented to its full. In this way, Croatian insurance market has become a part of the European single insurance market. Hence, an increase in competition by removing barriers to entry can be expected. For example, Šebjan and Tominc (2015 p. 42), while investigating Slovenian insurance industry that joined EU in 2005, noticed "an increase in competition especially with the emergence of new foreign insurance companies." The same authors also state that time based competition, quality, product range and services created a more competitive environment.

The soundness of insurers is of great importance for the insured since the indemnities that are to be paid depend on the reliability of the insurer. It is important for investors and policyholders since, according to Cummins, Rubio-Misas, and Vencappa (2017, p. 1), citing Das et al. (2003), "...insurance industry has significant potential to disrupt the financial system and negatively impact the economy". Moreover, as stated by Shim $(2015$, p. 2), "the relationship between changes in market concentration and financial stability of insurers is an important question for policy-makers who develop policies about industry structure including M\&A guidelines and market competitiveness. The empirical evidence on this issue can provide important implications for insurance regulators who are concerned about safety of insurers and seek to ensure the financial soundness of insurance market." RubioMisas and Fernández-Moreno (2017) also confirm that the risk of insolvency is of foremost importance for both regulators and consumers stating that "regulators are interested in limiting excessive insolvency risk to avoid a potential problem of contagion to other insurers due to a spike in insurer insolvencies." It is noteworthy citing Pasiouras and Gaganis (2013, p. 632) stating that "changes in the operating environment of insurance firms...combined with the fact that risk is by definition an integral part of the insurance industry poses great challenges to policy makers who try to endorse regulations that reduce insolvency risk and promote confidence in the financial stability of the insurance sector."

The analysis is conducted in two parts. Firstly, we estimate the Boone indicator of competition based on insurers' profits (Boone 2008) in Croatian insurance market in both analysed periods, i.e. from 2008 till 2012 and from 2013 till 2017 in order to see how competition has evolved over that time. In other words, we wanted to see whether joining the EU and opening up of Croatian insurance market to cross-border competitors actually increased competition measured with the Boone indicator. Furthermore, we test the impact of competition on the performance of efficient insurers, i.e. to see whether competition reallocates profits from inefficient to efficient insurers according to the efficient structure hypothesis. Secondly, we investigate the influence of competition measured by the Boone indicator on soundness of Croatian insurance companies in the pre-accession as well as in the post-accession period. The authors estimate a balanced panel data set with soundness (Z-score) as dependent variable whereas independent variables consist of the Boone competition indicator as well as of a set of insurance company - specific, insurance industry - specific and macroeconomic variables. Specifically, the authors wanted to test the transmission mechanism hypothesis proposed by Shaeck and Cihák (2014) stating that competition measured by the Boone indicator improves financial stability with efficiency being the transmission mechanism through which companies increase financial stability.

This research adds to the literature by providing, to the best of authors' knowledge, the first analysis of competition measured with the Boone indicator in the insurance industry in a post-transition economy such as Croatian as well as its effect on soundness. Croatian insurance market has been chosen for several reasons. First of all, Croatia has become a part of integrated EU market as latest member state and it is expected that becoming a part of single European market would have effects on the level of competition. Its insurance sector is important part of total financial sector while the adoption of new regulations as a part of the process of becoming an EU member state has posed challenges but also offered opportunities for insurers. Furthermore, efficiency, as an indirect 
measure of competition, has been largely investigated on the sample of European insurance markets (e. g. Medved and Kavčič 2012; Fenn et al. 2008; Cummins and Rubio-Misas 2006; Cummins, Rubio-Misas, and Zi 2004; Mahlberg and Url 2003; Cummins and Turchetti 1996). However, only a few studies have employed the Boone indicator in the context of insurance industry. E.g. Cummins, Rubio-Misas, and Vencappa (2017) investigated competition and soundness on the sample of 10 European life insurance markets while Bikker and van Leuvensteijn (2008) and Bikker (2014) focus on Dutch insurance industry. Therefore, our paper tries to fill the gap in the already scarce empirical literature by providing new evidence on competition and its effects on financial soundness of insurers in Croatia as well as in post-transition economy in general. Another contribution to the literature can be found in the fact that this paper analyses how competition measured with the Boone indicator has evolved and tests its influence on soundness of Croatian insurance market by comparing pre and post-EU accession period.

\section{LITERATURE REVIEW}

Cummins, Rubio-Misas, and Vencappa (2017) analyse relationship between soundness measured with a Z-score and competition measured with the Boone indicator in a cross - country context, i.e. on the sample of ten EU life insurance markets in the period 1999 - 2011. The authors firstly try to understand the evolution of competition after the deregulation process and to investigate the link between competition, efficiency and soundness using insurance-specific and country-specific variables. The results of the analysis reveal that for most of the countries competition level has decreased or remained the same. Furthermore, the authors analysed the effects of competition on $Z$-score as well as on each of the three components of $Z$-score. The key findings show that competition positively influences soundness, however, this effect is less evident for financially healthy insurers. Moreover, competition motivates EU life insurance companies to hold less capital.

In his investigation of influence of market concentration on financial stability, Shim (2015) employed $Z$-score as a measure of financial stability. The analysis is conducted on the sample of U.S. property - liability insurance companies over the period $1992-2010$. The author firstly conducts company-wise analysis and additionally performs state-wise analysis. In the company-wise analysis the author employs both OLS and 2SLS estimation techniques forming models with market concentration measured with both net premiums written and total assets. The finding of the analysis indicates that higher market concentration is related with lower financial stability. Furthermore, firm-specific variables consisting of size, underwriting leverage, form of mutual, geographical and product diversification, changes in interest rates as well as severe damages from natural catastrophes have significant impact on sound insurance system.

Pasiouras and Gaganis (2013) provide cross-country empirical study of the relationship between insurers' soundness measured with Z-score and regulatory policies. The authors use a wide range of regulations by constructing a capital requirements index, an official supervisory power index, a technical provisions index, an investment index and a corporate governance and internal control index controlling for various firm-specific and country-level attributes. The analysis is conducted using a dataset of over 1700 insurers from 46 countries. The findings are that in some models capital requirements have a negative impact on insurer's soundness while the power of supervisory authorities and regulation related to technical provisions and investment also significantly influence $Z$-score.

Shim (2011) examines M\&A activities, diversification and performance in the U. S. property-liability insurance industry in the period 1989 - 2004 using the risk-adjusted $\mathrm{ROA}, \mathrm{ROE}, \mathrm{Z}$-score and total risk measured by earnings volatility as a relevant performance measure. Firm features that affect insurers' performance are included as explanatory variables and consist of size, square of firm size, the ratio of equity capital to total assets, investment income, geographical diversity index, distribution system variables, organizational form dummy, unaffiliated companies dummy as well as M\&A year dummies. The key results when performance is presented with Z-score are that mergers and acquisitions have a negative impact on the insurer's financial performance. The same is true for product diversity, square of natural logarithm of assets and mixed distribution whereas share of commercial line, natural log of assets, equity to total assets ratio, brokerage, unaffiliated single firms and mutual positively affect $Z$-score.

Bikker and van Leuvensteijn (2008) explore competition and efficiency on the sample of Dutch life insurance industry. Regarding competition, the authors use five indirect measurement approaches consisting of tight oligopoly analysis, the scale efficiency level, the x-efficiency level, the profit margin and the Boone indicator. Estimates of the Boone indicator imply weak competition in the life insurance industry compared to the manufacturing and services industries. Moreover, all five competition indicators used in the analysis indicate weakening of competition. 


\section{DESCRIPTION OF VARIABLES}

The dependent variable used in the model, i.e. the soundness of insurance markets is represented with Z-score, an accounting measure of financial stability that has been used in insurance sector (Cummins, Rubio-Misas, and Vencappa 2017; Shim 2015; Pasiouras and Gaganis 2013; Shim 2011) and, to a much larger extent, in the banking sector (Schaeck and Cihák 2014; Bourkhis and Nabi 2013; DemirgüçKunt and Detragiache 2011; Demirgüç-Kunt and Huizinga 2010; Laeven and Levine 2009).

Insurance soundness as dependent variable is presented with Z-score expressed by following equation:

$$
Z=\frac{R O A+E / A}{\sigma_{R O A}}
$$

where ROA is a measure of profitability and stands for return on assets. $\mathrm{E} / \mathrm{A}$ is a measure of capitalization, i.e. equity to assets ratio. If the capital ratio increases, together with profitability, Z-score will increase as well indicating better soundness or lower probability of default (Shim 2015). Therefore, it can be observed as a measure of financial strength. Moreover, oROA represents the return of volatility expressed by the standard deviation of return on assets. According to Shim (2011, p. 125), Z-score is a proxy measure of the likelihood of insurer insolvency and a function of the insurer's profit ratio, the variation in that profit ratio, and the equity capital available to absorb that variation. Moreover, Stiroh and Rumble (2006, p. 2138) state that it measures the number of standard deviations that profits must fall to drive a company into default. The $Z$-score is inversely related to the probability of failure, with higher Z-score suggesting a lower probability of default. Shim (2015) notes that the Z-score increases as an insurers' profitability and capital ratio increase, and the Z-score declines with increasing volatility of asset returns. Moreover, following Cummins, Rubio-Misas, and Vencappa (2017) and Pasiouras and Gaganis (2013) approach, we use the natural logarithm of the $Z$-score to control for non-linear effects and outliers.

Independent variable employed in the analysis is indirect measure of competition, the Boone indicator (Boone), based on the concept that competition rewards efficiency and penalises inefficiency, according to the efficient structure hypothesis. In competitive markets, efficient firms perform better and, according to Bikker and van Leuvensteijn (2008, p. 2071), the Boone indicator measures the extent to which efficiency differences between firms are translated into performance differences. The same authors also emphasize the advantage of the Boone indicator that is reflected in the fact that "it is more directly linked to competition than measures such as scale economies and X-inefficiency or ... misleading measures as the concentration ratio" or moreover, as stated by Cummins, Rubio-Misas, and Vencappa (2017, p. 3), “...direct measures of competition traditionally employed in the industrial organisation literature such as the Herfindahl-Hirschman index, concentration ratios... are known to suffer from theoretical and empirical difficulties."

When testing the impact of competition on the performance of efficient insurers, this variable is expected to have negative sign because relatively efficient firms make higher profits, i.e., according to the efficient structure hypothesis, competition reallocates profits from inefficient to efficient insurers. Specifically, as stated by Cummins, Rubio-Misas, and Vencappa (2017, p. 18), lower (more negative) values of the Boone indicator imply stronger competition.

When investigating the influence of competition measured by the Boone indicator on soundness of Croatian insurance we expect it to have a negative sign indicating positive influence of competition on soundness as found by Cummins, Rubio-Misas, and Vencappa (2017) providing support to the transmission mechanism hypothesis.

Furthermore, several control variables at firm-level, industry-level and macroeconomic variables are included in the analysis. Their description and expected influence on dependent variable are described in rows below.

Reinsurance ratio (re) is calculated as share of premium ceded to reinsurance in total gross written premium. It is included in the analysis as a firm level variable and its influence on soundness of an insurance company is uncertain. It is expected to have positive effect on soundness of insurance companies since reinsurance reduces insolvency risk and strengthens the financial viability of insurance firms (Cummins et al. 2008, p. 1). However, transferring risk to reinsurers comes at a certain cost. Kim et al. (1995) investigated how reinsurance is related to insolvencies of insurers finding, in some models, that the more the insurer is exposed to its reinsurer, the more it is exposed to the negative financial influence of a reinsurer failure. Therefore, the negative influence of this variable on the soundness of insurers might be expected as well. Finally, as stated by Weiss and Choi (2008, p. 143), reinsurance might increase cost, leading to higher prices and/or lower profit. On the contrary, if reinsurance activities considerably improve diversification of risk among the policyholder pool, reinsurance might reduce price and profit because of lower net pooling risk. 
Size (In_assets) variable is another firm-specific variable often employed in insurance empirical research (e.g. Cummins, Rubio-Misas, and Vencappa 2017; Rubio-Misas and Fernández-Moreno 2017; Shim 2015; Weiss and Choi 2008; Wand, Jeng, and Peng 2007; Shiu 2004; Adams and Buckle 2003; O'Sullivan and Diacon 2003; Cummins, Tennyson, and Weiss 1999). According to Shiu (2004, p. 1083), who investigated determinants of insurance companies' performance, large insurance companies usually have a greater ability for dealing with adverse market oscillations and can recruit capable employees with professional knowledge rather easily resulting in better performance. Moreover, Adams and Buckle (2003, p. 135) add that large corporate size enables insurers to successfully diversify their assumed risks and react more quickly to fluctuations in market environments. As stated by Cummins and Nini (2002, p. 29), firm size is expected to be positively related to efficiency if larger firms have lower insolvency risk and/or are able to earn higher revenues because size conveys market power. However, there are opposite arguments as well. The same authors, citing Pi and Timme (1993), emphasize that financial performance could be inversely associated to company size since it often becomes more difficult for owners to efficiently and effectively monitor managers as company grows. Furthermore, financial performance could be negatively affected in large organizations due to the diseconomies of scale. In the end, Adams and Buckle (2003, p. 135) state that most of the recent empirical evidence for international insurance markets suggest that larger companies outperform smaller ones. Since the positive relation between firm size and performance is theoretically supported by the economies of scale concept, we expect its positive impact on soundness of insurers.

Premium to surplus ratio (prem_surplus) has been included in the analysis following Cummins, Rubio-Misas, and Vencappa (2017), Shim (2015); Cummins and Nini (2002) and Cummins, Weiss, and Zi (1999) in order to capture financial aspect of the insurance companies' activities. It is calculated as the net premium to equity, i.e. surplus representing an insurance leverage ratio. It is used to measure the capacity of an insurance company to underwrite new policies. A low premium to equity ratio is considered a sign of financial strength because the insurer is using its capacity to write more policies. On the contrary, a higher premium to surplus ratio indicates that the insurer has lower capacity. Therefore, the negative effect of this variable on soundness of an insurer is expected.

Gross written premium growth (gwp_growth) is measured as percentage change in gross written premium of each insurer in each year calculated as

$$
\frac{G W P_{t}-G W P_{t-1}}{G W P_{t-1}} \text {. }
$$

Rubio-Misas and Fernández-Moreno (2017) while evaluating determinants of insurer regulatory solvency ratio included premium growth variable stating that premium growth without a parallel equity capital growth increases the insurer insolvency risk. Furthermore, Chen and Wong (2004, p. 471) state that "being too obsessed with growth can lead to self-destruction as other important objectives might be neglected". Therefore, we expect negative influence of this variable on soundness of insurance companies.

Variable ownership (own) was introduced in the model as a dummy variable taking the value 1 if an insurer is domestically owned and 0 if an insurer is in foreign ownership (more than $50 \%$ controlled by foreign shareholders). This industry-specific or structure variable was employed since insurance sector in Croatia is characterised by the high percentage of assets in foreign ownership and the authors wanted to find its influence on soundness of insurers. We expect foreign owned insurance companies to have positive impact on soundness since a reason why firms invest abroad lies in the fact that they possess superior capabilities (Majumdar, 1997, p. 234). The author adds that the possession of these capabilities may lead a firm to exhibit greater performance compared to domestically-controlled firms. Kozak (2011) finds that the increase of foreign ownership positively contributes to the insurance companies profitability on the sample of Polish insurance companies.

Control variable included in the model in order to capture for macroeconomic conditions is inflation rate (inf), specifically, average CPI year-on-year inflation rate, following Cummins, Rubio-Misas, and Vencappa (2017, p. 18) who state that better economic conditions as reflected in lower inflation level are expected to increase competition and we consequently expect its negative effect on soundness of an insurer. Moreover, Pasiouras and Gaganis (2013) use the inflation rate as a proxy for monetary instability. According to Demirgüç-Kunt and Detragiache (1998) this variable is likely to be associated with high nominal interest rates and it may proxy macroeconomic mismanagement, which unfavourably affects the economy. Moreover, it provides evidence on whether the local currency provides a stable measure of value in longterm contracting (Demirgüç-Kunt and Maksimovic 1999, p. 304) which is particularly important in life insurance that is long-term in nature.

Another control variable encompassed by the model in order to reflect macroeconomic environment 
is GDP growth rate (GDP_growth). A more thorough review when GDP growth rate is used to represent economic growth is provided in paper by Chirwa and Odhiambo (2016). As suggested by Pasiouras and Gaganis (2013, p. 635), citing Demirgüc-Kunt and Detragiache (1998), „problems in the financial sector are more likely to emerge when the growth is low". If the macroeconomic environment worsens, this may cause a threat to soundness of financial companies, therefore, positive influence of this variable is expected.

\section{SAMPLE CONSTRUCTION AND DATA SOURCES}

Our sample consists of all licensed insurance companies (life, non-life and composite) that operated in the periods of the analysis, i.e. in 2008 - 2012 and in 20132017 period. Those companies that have not been operating in each year of the observed period were omitted from the analysis. Our final research sample relating to the pre-EU accession period consists of 13 companies making a total of $87 \%$ of the market or 65 observations while the research sample relating to the post-EU accession period consists of 19 companies per year making a total of $98 \%$ of the market in 2017 or 95 observations. Furthermore, it refers to domestic activities only whereas reinsurance companies have been omitted from the analysis.

The authors calculated all firm specific and industry specific variables used in this research using the data from different sources. Specifically, the data on total assets, total gross written premium and net profit after taxes are sourced from regular publications by Croatian Financial Services Supervisory Agency (HANFA). Data on net incurred claims, operating expenses, net premiums, net investment income, premiums ceded to reinsurance and equity capital were manually collected form insurers' annual reports publicly available through Croatian Financial Agency (FINA). Moreover, the data for dummy variable ownership were taken from annual reports published by Croatian Insurance Bureau (HUO). Finally, the data on average CPI year-on-year inflation rate and GDP growth rate have been taken directly from Croatian National Bank (HNB) web pages.

\section{EMPIRICAL FINDINGS}

First step in an empirical research was to calculate the Boone indicator. We follow Cummins, Rubio-Misas, and Vencappa (2017) approach with the Boone indicator being empirically constructed form the modified regression equation:

$$
\pi_{i t}=\alpha+\beta \ln \left(a c_{i t}\right)+\varepsilon_{i t}
$$

where $\Pi_{i t}$ is the profit of the insurer $i$ in year $t$ as a proportion of its total assets, the Boone indicator is presented by the parameter $\beta, a c_{i t}$ is average variable costs serving as a proxy for marginal costs, while $\varepsilon_{i t}$ is the error term. This modified regression equation uses average costs as a proxy for marginal costs following Cummins, Rubio-Misas, and Vencappa (2017), Shaeck and Cihák (2014) and Bikker and van Leuvensteijn (2008) approach since marginal costs cannot be observed directly. With the aim of constructing variables in the above mentioned equation we have employed Cummins, Rubio-Misas, and Vencappa (2017) approach and we measure profits as the difference between variable revenues and variable costs divided by total assets. Furthermore, average variable costs are represented by variable costs to variable revenues ratio with variable costs consisting of the net incurred claims and operating expenses while variable revenues is the sum of net premiums and net investment income. Linear regression was conducted for every year from 2008 to 2017 and results are presented with Table 1.

Table 1 shows that the values of the Boone indicator, which were estimated using linear regression, were statistically significant in each year of the analysis encompassing pre- and post-EU accession period. It ranges from -0.2536 in 2016 and 0.4142 in 2010 respectively. Having in mind that lower the value of the Boone indicator the higher the competition, it can be observed that competition levels have considerably

Table 1: Values of the Boone Indicator in the Croatian Insurance Industry in the Pre-EU and Post-EU Accession Period

\begin{tabular}{|c|c|c|c|c|}
\hline \multicolumn{2}{|c|}{ Year } & $\begin{array}{l}\text { The Boone } \\
\text { indicator }\end{array}$ & $p$ value & R-squared \\
\hline \multirow{5}{*}{ 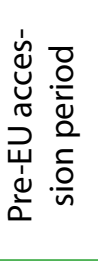 } & 2008 & 0.1763 & 0.0000 & $88.76 \%$ \\
\hline & 2009 & 0.3589 & 0.0000 & $65.76 \%$ \\
\hline & 2010 & 0.4142 & 0.0000 & $68.25 \%$ \\
\hline & 2011 & 0.1155 & 0.0000 & $57.17 \%$ \\
\hline & 2012 & 0.3150 & 0.0000 & $97.37 \%$ \\
\hline \multirow{5}{*}{ 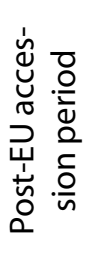 } & 2013 & -0.1689 & 0.0000 & $79.96 \%$ \\
\hline & 2014 & -0.1555 & 0.0000 & $84.88 \%$ \\
\hline & 2015 & -0.1746 & 0.0000 & $91.58 \%$ \\
\hline & 2016 & -0.2536 & 0.0000 & $95.85 \%$ \\
\hline & 2017 & -0.1718 & 0.0000 & $89.17 \%$ \\
\hline
\end{tabular}

Source: authors' calculations 
increased after the accession to the EU. Becoming a part of a single EU market followed by a decline in barriers to entry exposing insurance companies to higher cross-border competition has led to an increase of competition. Specifically, in each year in the post-EU accession period the Boone indicator achieves negative values reflecting the fact that more efficient insurer (with lower average costs) makes higher profits. On the contrary, the opposite is found on the sample of insurance companies that operated in the period prior to the accession to EU, when positive coefficients of the Boone indicator were obtained indicating lower competition. Although, as stated by Van Leuvensteijn et al. (2011) it is not uncommon to find positive values of the Boone indicator and there is no specified threshold to categorize a market as being competitive or not. E.g. Cummins, Rubio-Misas, and Vencappa (2017) have found positive values of the Boone indicator for Swedish insurance market in the period 1999 2011 as well as Van Leuvensteijn et al. (2011) for some years in Japanese, French, Dutch and UK loan markets. The dynamics of the Boone indicator over time are also shown by Figure 1.

The particularly low level of the Boone indicator in 2016 indicating the highest level of competition can be explained by the increase in profits in this particular year. On the contrary, rationale for the highest level of the Boone indicator, i.e. the lowest level of competition achieved in 2010 is in line with a wave of consolidations that occur in $\mathbf{2 0 1 0}$ helping to foster a less competitive environment.

After estimating the Boone indicator, the next step in the research was to employ static panel analysis where we investigated the influence of independent variables on soundness of insurance companies, i.e. on dependent variable Z-score. For the purpose of econometric data analysis, we employed static balanced panel data analysis. Model (3) forms the basis of our estimation.

$$
\begin{aligned}
& Y_{i t}=c+\sum_{k=1}^{K} \beta_{k} X_{i t}^{k}+\varepsilon_{i t} \\
& \varepsilon_{i t=Z_{i}}+u_{i t},
\end{aligned}
$$

where:

- $Y_{i t}$ is a measure of soundness for insurer $i$ at time $t$, presented with the $Z$-score.

- $X_{i t}$ are $\mathrm{k}$ independent variables including the Boone indicator, reinsurance ratio, size, premium to surplus ratio, gross written premium growth, ownership, inflation rate and GDP growth rate, $\varepsilon_{i t}$ is the disturbance with $z_{i}$ being the unobserved insurancespecific effect and $u_{i t}$ being the idiosyncratic error. The presented model is a one-way error component regression model where $z_{i} \sim \operatorname{IIN}\left(0, \sigma_{z}^{2}\right)$ and independent of $u_{i t} \sim \operatorname{IIN}\left(0, \sigma_{u}^{2}\right)$.

We follow Schaeck and Cihák (2014) and Cummins, Rubio-Misas, and Vencappa (2017) approach using a three-year rolling window for $\sigma_{\mathrm{ROA}}$, i.e. to calculate the 2013 Z-scores we use data from 2011-2013 period and so on. This is to allow for variation in the denominator of the Z-score since it avoids that the Z-scores are exclusively driven by variation in the levels of capital and profitability.

Descriptive statistics for all variables used in the

Figure 1: Dynamics of the Boone Indicator in the Croatian Insurance Industry in the Pre-EU and Post-EU Accession Period

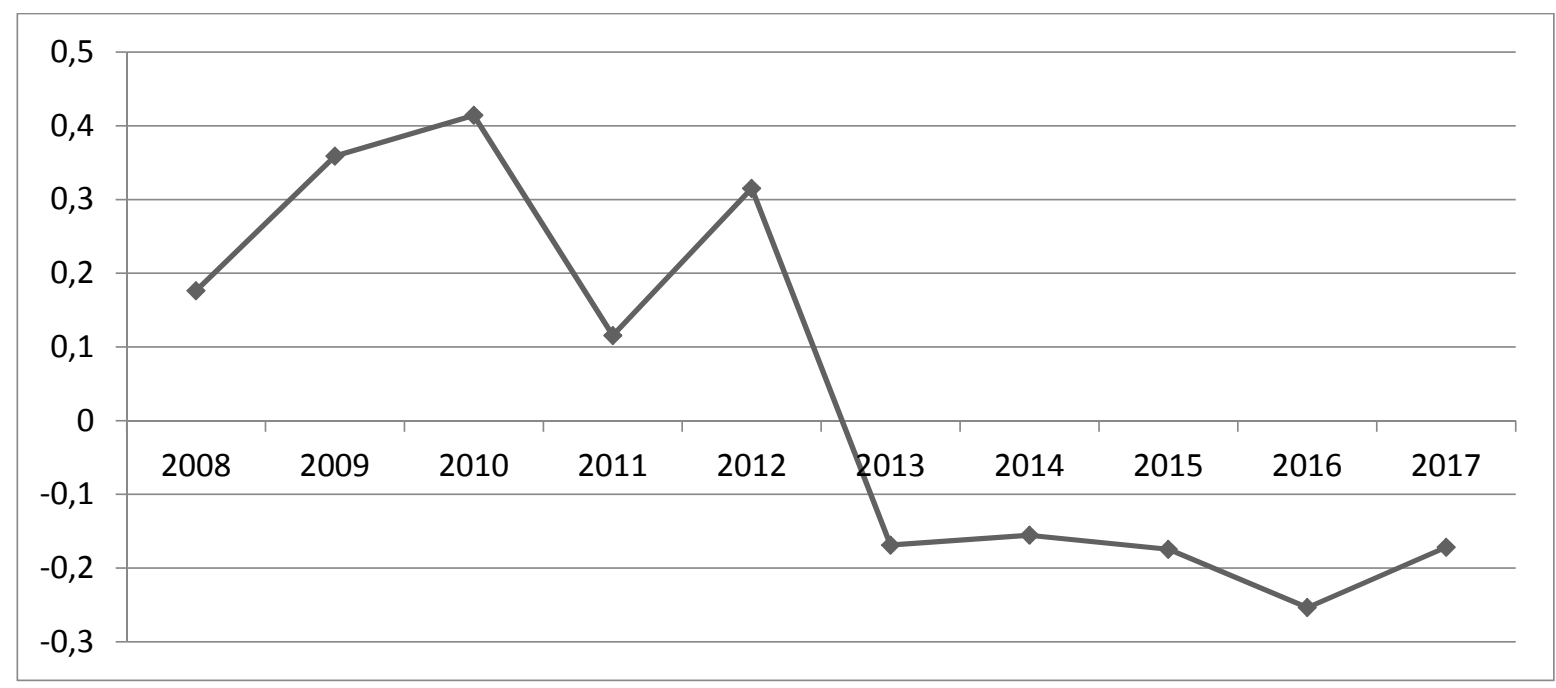

Source: authors' calculations 
Table 2: Descriptive Statistics of the Variables in the Pre-EU Accession Period (2008-2012)

\begin{tabular}{|l|c|c|c|c|c|}
\hline Variable & Obs & Mean & Std. Dev. & Min & Max \\
\hline InZ & 65 & 3,4448 & 1,5444 & 0,0458 & 6,7968 \\
\hline Boone & 65 & 0,2760 & 0,1133 & 0,1155 & 0,4142 \\
\hline In_assets & 65 & 20,8384 & 1,1700 & 18,1190 & 22,8219 \\
\hline re & 65 & 0,0981 & 0,1164 & 0,0000 & 0,4118 \\
\hline prem_surplus & 65 & 1,9483 & 1,1953 & 0,0008 & 6,6841 \\
\hline gwp_growth & 65 & 0,0602 & 0,3209 & $-0,1238$ & 2,4981 \\
\hline own & 65 & 0,5538 & 0,5010 & 0,0000 & 1,0000 \\
\hline inf & 65 & 0,0306 & 0,1699 & 0,0110 & 0,0610 \\
\hline GDP_growth & 65 & $-0,0188$ & 0,0310 & $-0,0730$ & 0,0200 \\
\hline
\end{tabular}

Source: authors' calculations

Table 3: Descriptive Statistics of the Variables in the Post-EU Accession Period (2013-2017)

\begin{tabular}{|l|c|c|c|c|c|}
\hline Variable & Obs & Mean & Std. Dev. & Min & Max \\
\hline InZ & 95 & 3,8808 & 1,3242 & 0,8031 & 7,7735 \\
\hline Boone & 95 & $-0,1849$ & 0,0352 & $-0,2536$ & $-0,1555$ \\
\hline In_assets & 95 & 20,3964 & 1,6587 & 17,5200 & 23,0000 \\
\hline re & 95 & 0,1165 & 0,1437 & 0,0001 & 0,8277 \\
\hline prem_surplus & 95 & 0,9212 & 0,5929 & 0,0013 & 2,4754 \\
\hline gwp_growth & 95 & 0,1596 & 0,7560 & $-0,9053$ & 6,6673 \\
\hline own & 95 & 0,3789 & 0,4877 & 0,0000 & 1,0000 \\
\hline inf & 95 & 0,0030 & 0,0120 & $-0,0110$ & 0,0220 \\
\hline GDP_growth & 95 & 0,0164 & 0,0164 & $-0,0050$ & 0,0350 \\
\hline
\end{tabular}

Source: authors' calculations

research are provided in Table 2 and Table 3 separately for pre- and post-EU accession period.

Since the use of independent variables can lead to distorted and unrealistic valuation of contributions of individual independent variables when explaining the dependent variable, before panel data analysis was conducted, multicollinearity was tested. We have used variance inflation factors (VIFs) to check for multicollinearity. Since a variable whose VIF values are greater than 5 may indicate a certain degree of collinearity, we can see from tables 4 and 5 , that there is no multicollinearity problem between independent variables so none of the independent variables was omitted from the further analysis. This relates to both pre- and postEU accession period.

After examining problem of multicollinearity between independent variables, we tested the presence of heteroscedasticity. If the error terms do not have constant variance, they are heteroskedastic. If the heteroscedasticity is present, the standard errors are biased. This can lead to bias in test statistics and confidence intervals. To test the presence of heteroscedasticity Breusch-Pagan test for heteroscedasticity was fitted in research. The results of Breusch-Pagan test are given in Tables 6 and 7 .

The result of Breusch-Pagan test for heteroscedasticity shows that heteroscedasticity is not present.

Table 4: Test for Multicollinearity using VIFs in the Pre-EU Accession Period (2008-2012)

\begin{tabular}{|l|c|c|}
\hline Variable & VIF & 1/VIF \\
\hline Boone & 1.77 & 0.564010 \\
\hline In_assets & 1.24 & 0.808564 \\
\hline re & 1.73 & 0.576953 \\
\hline prem_surplus & 1.22 & 0.817977 \\
\hline gwp_growth & 1.29 & 0.775863 \\
\hline own & 1.80 & 0.555379 \\
\hline inf & 1.62 & 0.617599 \\
\hline GDP_growth & 1.75 & 0.571609 \\
\hline
\end{tabular}

Source: authors' calculations 
Table 5: Test for Multicollinearity using VIFs in the Post-EU Accession Period (2013-2017)

\begin{tabular}{|l|l|l|}
\hline Variable & VIF & $1 /$ VIF \\
\hline Boone & 1.97 & 0.508597 \\
\hline In_assets & 1.09 & 0.916220 \\
\hline re & 1.05 & 0.948555 \\
\hline prem_surplus & 1.06 & 0.943722 \\
\hline gwp_growth & 1.11 & 0.899761 \\
\hline own & 1.06 & 0.946125 \\
\hline inf & 1.61 & 0.619867 \\
\hline GDP_growth & 2.01 & 0.496453 \\
\hline
\end{tabular}

Source: authors' calculations

Table 6: Tests for Heteroscedasticity in the Pre-EU Accession Period (2008-2012)

\begin{tabular}{|l|c|c|}
\hline Tests & chi2 & p value \\
\hline Breusch-Pagan & 0.18 & 0.6732 \\
\hline
\end{tabular}

Source: authors' calculations

Table 7: Tests for Heteroscedasticity in the Post-EU Accession Period (2013-2017)

\begin{tabular}{|l|c|c|}
\hline Tests & chi2 & p value \\
\hline Breusch-Pagan & 1.40 & 0.2361 \\
\hline
\end{tabular}

Source: authors' calculations

After examining the multicollinearity problem and heteroscedasticity, static panel with fixed effects and static panel with random effects were employed in the research. Hausman test shows that the most appropriate model in the pre-EU accession period was static panel model with random effects whereas in the post-EU accession period was static panel model with fixed effects. Table 8 shows the results of the analysis.

The results of the analysis relating to the pre-EU accession period show that variables that significantly influence soundness of insurance companies are premium to surplus ratio and inflation rate. Specifically, inflation rate is having positive effect whereas premium to surplus ratio has negative impact on soundness. The negative effect of premium to surplus ratio on soundness of insurance companies is expected since its lower values reflect the capacity of an insurance company to underwrite new policies as its financial strength. In other words, when premiums increase with a corresponding increase in policyholders' surplus, the capacity of the insurer to write new policies
Table 8: Parameter Estimates of Static Panel Model

\begin{tabular}{|c|c|c|}
\hline & $\begin{array}{c}\text { Pre-EU Accession } \\
\text { Period }\end{array}$ & $\begin{array}{c}\text { Post-EU Accession } \\
\text { Period }\end{array}$ \\
\hline Boone & $\begin{array}{c}1.623555 \\
(1.553353)\end{array}$ & $\begin{array}{c}3.040563 \\
(3.359805)\end{array}$ \\
\hline In_assets & $\begin{array}{l}-0.0479183 \\
(0.2139803)\end{array}$ & $\begin{array}{c}-0.329966 \\
(0.4713864)\end{array}$ \\
\hline re & $\begin{array}{c}1.261647 \\
(2.650838)\end{array}$ & $\begin{array}{l}-0.9255606^{*} \\
(0.5226914)\end{array}$ \\
\hline prem_surplu & $\begin{array}{c}-0.4566575^{* * *} \\
(0.1539544)\end{array}$ & $\begin{array}{l}-0.0855169 \\
(0.3105307)\end{array}$ \\
\hline gwp_growth & $\begin{array}{c}0.0722179 \\
(0.5021237)\end{array}$ & $\begin{array}{l}-0.0614958 \\
(0.1483031)\end{array}$ \\
\hline own & $\begin{array}{c}0.8953841 \\
(0.6260799)\end{array}$ & $\begin{array}{c}-1.043182 \\
(0.9623119)\end{array}$ \\
\hline inf & $\begin{array}{c}20.47096^{* *} \\
(10.1053)\end{array}$ & $\begin{array}{c}2.249667 \\
(8.932313)\end{array}$ \\
\hline GDP_growth & $\begin{array}{l}-0.3300498 \\
(5.632292)\end{array}$ & $\begin{array}{l}18.3569^{* *} \\
(7.779113)\end{array}$ \\
\hline cons & $\begin{array}{c}3.628345 \\
(4.608837)\end{array}$ & $\begin{array}{c}11.47828 \\
(9.674611)\end{array}$ \\
\hline R2 within & 0.1404 & 0.1397 \\
\hline R2 between & 0.6236 & 0.0817 \\
\hline $\mathrm{R} 2$ overall & 0.4006 & 0.0241 \\
\hline \multirow{2}{*}{ Hausman test } & chi $=7.71$ & chi $=17.35$ \\
\hline & $p$ value $=0.4627$ & $p$ value $=0.0039$ \\
\hline
\end{tabular}

$*^{* * *},{ }^{* * *}$ Statistically significant at the; $10 \%, 5 \%, 1 \%$ level, respectively. Standard errors are between parentheses.

Source: authors' calculation

is increasing. Its negative influence on Z-score is also confirmed by Cummins, Rubio-Misas, and Vencappa (2017) and Shim (2015). Contrary to our expectations, inflation rate positively influences soundness. This can be explained by the fact that higher inflation rates might lead to irrational pricing and subsequently high levels of premiums written and profits. The same is found by Cummins, Rubio-Misas, and Vencappa (2017) although its influence is not statistically significant whereas its negative influence is found by Pasiouras and Gaganis (2013). It is important to note that competition measured with the Boone indicator as well as size of the insurer, use of reinsurance, premium and GDP growth as well as ownership do not influence insurers' soundness in pre-EU accession period.

The results of the analysis relating to the post-EU accession period reveal that variables having statistically significant influence on soundness of insurance 
companies are share of reinsurance and GDP growth. Specifically, use of reinsurance has negative influence on soundness of insurance companies whereas, as expected, GDP growth rate positively affects soundness in the period 2013-2017. Regarding the negative influence of reinsurance on financial stability of insurance companies, this can be explained by the fact that shifting risk to reinsurers is costly and insurance companies utilizing more reinsurance are not financially sounder. This is also confirmed by Shim (2015) while Cummins et al. (2008) suggest that reinsurance increases significantly the costs of producing insurance services. Furthermore, Rubio-Misas and FernándezMoreno (2017) analysing the financial strength of Spanish insurers employed several factors including the use of reinsurance finding its negative influence on the level of the regulatory solvency ratio. Since GDP growth rate stands for a general indicator of economic development, its positive and statistically significant influence on insurers' soundness suggest that in robust macroeconomic environment characterised by higher GDP growth rates, it is less likely that problems in insurance will occur. This is also supported by findings by Pasiouras and Gaganis (2013), Fu, Lin, and Molyneux (2014) and Cummins, Rubio-Misas, and Vencappa (2017). Other variables, such as Boone indicator, size, premium to surplus ratio, premium growth, ownership and inflation do not significantly determine the soundness of insurance companies in the period after accession to the EU.

\section{ROBUSTNESS CHECKS}

The authors subject their findings to robustness test. When calculating Z-score we have initially employed a three-year rolling window for calculation of standard deviation of ROA. As a robustness test, the authors follow Pasiouras and Gaganis (2013) approach and re-estimate the model using a four-year rolling window. Although, using a longer period for calculation of standard deviation of ROA might result in more reliable $Z$-score, the negative consequence is inevitable loss of observations since it is difficult to meet the requirement of having, for example, eight years of continuous information per insurer.

The analysis reveals that main results are robust to using a four-year rolling window, i.e. the results are similar to those obtained when using a three-year rolling window as presented with Table 9.

Specifically, the results of robustness test relating to the pre-EU accession period are identical to those when using three-year rolling window, i.e. premium to surplus ratio and inflation rate have statistically
Table 9: Results of the Robustness Checks

\begin{tabular}{|c|c|c|}
\hline & $\begin{array}{c}\text { Pre-EU Accession } \\
\text { Period }\end{array}$ & $\begin{array}{c}\text { Post-EU Accession } \\
\text { Period }\end{array}$ \\
\hline Boone & $\begin{array}{c}1.242538 \\
(1.162807)\end{array}$ & $\begin{array}{l}-2.481344 \\
(4.234831)\end{array}$ \\
\hline In_assets & $\begin{array}{c}-0.125147 \\
(0.1903986)\end{array}$ & $\begin{array}{l}-0.1605716 \\
(0.3260937)\end{array}$ \\
\hline re & $\begin{array}{c}-0.1449944 \\
(2.414862)\end{array}$ & $\begin{array}{r}-0.7668641 \\
(1.235355)\end{array}$ \\
\hline prem_surplu & $\begin{array}{c}-0.3812924^{* * *} \\
(0.1227104)\end{array}$ & $\begin{array}{l}-0.2902453 \\
(0.3418437) \\
\end{array}$ \\
\hline gwp_growth & $\begin{array}{l}-0.1479949 \\
(0.3814828)\end{array}$ & $\begin{array}{l}-0.6687597 \\
(0.9152054)\end{array}$ \\
\hline own & $\begin{array}{c}0.7566086 \\
(0.5671378)\end{array}$ & $\begin{array}{l}-0.6387362 \\
(0.5128552)\end{array}$ \\
\hline inf & $\begin{array}{l}13.30479^{* *} \\
(7.640037)\end{array}$ & $\begin{array}{c}12.3491 \\
(11.41682)\end{array}$ \\
\hline GDP_growth & $\begin{array}{l}-1.967062 \\
(4.212654)\end{array}$ & $\begin{array}{c}18.17051^{* * *} \\
(9.649369)\end{array}$ \\
\hline cons & $\begin{array}{c}5.363163 \\
(4.075629) \\
\end{array}$ & $\begin{array}{c}7.264684 \\
(7.319875)\end{array}$ \\
\hline R2 within & 0.1616 & 0.1711 \\
\hline $\mathrm{R} 2$ between & 0.4909 & 0.2897 \\
\hline $\mathrm{R} 2$ overall & 0.3961 & 0.2186 \\
\hline \multirow{2}{*}{ Hausman test } & $\mathrm{chi}=11.63$ & $\mathrm{chi}=3.90$ \\
\hline & $p$ value $=0.1687$ & $p$ value $=0.7907$ \\
\hline
\end{tabular}

$*^{* *},{ }^{* * *}$ Statistically significant at the; $10 \%, 5 \%, 1 \%$ level, respectively. Standard errors are between parentheses.

Source: authors' calculation

significant influence on soundness. Moreover, the results of robustness check relating to the post-EU accession period are similar to the results when threeyear rolling window has been employed with only GDP growth variable being statistically significant and positively influencing soundness of insurers.

\section{CONCLUSION}

After years of efforts and challenging accession negations, the Republic of Croatia has finally joined the European Union as of $1^{\text {st }}$ of July 2013. The accession to the EU has undoubtfully brought many changes especially in the regulatory environment since Croatia has become a part of single European market and barriers to entry have diminished. It is expected that this would be reflected in the level of competition in the 
insurance market that is the focus of our research. The competitive pressure on insurers has increased over the decades due to numerous reasons, but after July 2013 Croatian insurance companies are facing pressure from the global insurance community.

When measuring the level of competition, a novel approach, not largely exploited in the insurance empirical literature, introduced by Boone (2008) has been applied. The dynamics of the level of competition in the post accession years have not taken the uniform direction, but it clearly shows an increase in competition after joining the EU. It also shows that competition rewards efficiency. However, its influence on soundness was not significant in period relating to both pre- and post- EU accession. On the contrary, premium to surplus and inflation rate significantly affect soundness in the years preceding EU accession while after joining EU use of reinsurance and GDP growth are found to play significant role in determining insurers soundness.

With these findings, the authors hope to provide useful insights for both insurance industry supervisors and practitioners into what determines sound insurance market. Moreover, since the process of EU expansion would probably continue, it might be interesting to see how competition changes in new member states as well. As a suggestion for future research, the authors might consider the use of other variables as potential determinants of insurers' soundness while the cross-country comparison might be useful as well.

\section{REFERENCES}

Adams, M. and Buckle, M. 2003. The determinants of corporate financial performance in the Bermuda insurance market. Applied Financial Economics 13 (2): 133-143.

Bikker, J. A. 2014. Performance of the life insurance industry under pressure: efficiency, competition and consolidation 1-31., www.uu.nl/rebo/economie/discussionpapers (accessed October 20, 2018).

Bikker, J. A. and Van Leuvensteijn, M. 2008. Competition and efficiency in the Dutch life insurance industry. Applied Economics 40 (16): 2063-2084.

Boone, J. 2008. A new way to measure competition. The Economic Journal 118 (531): 1245-1261.

Bourkhis, K. and Nabi, M. S. 2013. Islamic and conventional banks' soundness during the 2007-2008 financial crisis. Review of Financial Economics 22 (2): 68-77.

Chen, R. and Wong, K. A. 2004. The determinants of financial health of Asian insurance companies. Journal of Risk and Insurance 71(3): 469-499.

Chirwa, T. G. and Odhiambo, N. M. 2016. Macroeconomic determinants of economic growth: A review of international literature. South East European Journal of Economics and Business 11(2): 33-47.

Croatian Financial Services Supervisory Agency (HANFA), Statistics, https://www.hanfa.hr/publikacije/ statistika/\#section 1 (accessed October 5, 2018).

Croatian Insurance Bureau, Statistical reports, Insurance Market in the Republic of Croatia in 2017, http://www. huo.hr/Listanje PDF/Trziste osiguranja RH 2017/index.html\#/0 (accessed October 5, 2018).

Croatian Insurance Bureau, Insurance Market in the Republic of Croatia 2017 - Key Facts, http://www.huo.hr/eng/ publications/50/ (accessed June 17, 2019).

Croatian National Bank (HNB), Main macroeconomic indicators, https://www.hnb.hr/en/statistics/main-macroeconomic-indicators (accessed October 5, 2018).

Cummins, J. D. and Nini, G. P. 2002. Optimal capital utilization by financial firms: Evidence from the property-liability insurance industry. Journal of Financial Services Research 21 (1-2): 15-53.

Cummins, J. D. and Rubio-Misas, M. 2006. Deregulation, consolidation, and efficiency: evidence from the Spanish insurance industry. Journal of Money, Credit and Banking 323-355.

Cummins, J. D., Rubio-Misas, M. and Vencappa, D. 2017. Competition, efficiency and soundness in European life insurance markets. Journal of Financial Stability 28: 66-78.

Cummins, J. D., Rubio-Misas, M. and Zi, H. 2004. The effect of organizational structure on efficiency: Evidence from the Spanish insurance industry. Journal of Banking \& Finance 28 (12): 3113-3150.

Cummins, J. D. and Turchetti, G. 1996. Productivity and technical efficiency in the Italian insurance industry (No. 9610). Wharton School Center for Financial Institutions, University of Pennsylvania.

Cummins, J., Dionne, G., Gagné, R. and Nouira, A. 2008. The costs and benefits of reinsurance. CIRRELT-2008-26, 1-32., $\quad$ https://www.cirrelt.ca/DocumentsTravail/ CIRRELT-2008-26.pdf (accessed November 7, 2018).

Cummins, J. D., Tennyson, S. and Weiss, M. A. 1999. Consolidation and efficiency in the US life insurance industry. Journal of Banking \& Finance 23 (2-4): 325-357.

Cummins, J. D., Weiss, M. A. and Zi, H. 1999. Organizational form and efficiency: The coexistence of stock and mutual property-liability insurers. Management Science 45 (9): 1254-1269.

Demirgüç-Kunt, A. and Detragiache, E. 2011. Basel Core Principles and bank soundness: Does compliance matter?. Journal of Financial Stability 7 (4): 179-190.

Demirgüç-Kunt, A. and Detragiache, E. 1998. The determinants of banking crises in developing and developed countries. Staff Papers 45 (1): 81-109. 
Demirgüç-Kunt, A. and Maksimovic, V. 1999. Institutions, financial markets, and firm debt maturity", Journal of Financial Economics 54: 295-336.

Demirgüç-Kunt, A. and Huizinga, H. 2010. Bank activity and funding strategies: The impact on risk and returns. Journal of Financial Economics 98 (3): 626-650.

Fenn, P., Vencappa, D., Diacon, S., Klumpes, P. and O'Brien, C. 2008. Market structure and the efficiency of European insurance companies: A stochastic frontier analysis. Journal of Banking \& Finance 32 (1): 86-100.

Fu, X. M., Lin, Y. R. and Molyneux, P. (2014). Bank competition and financial stability in Asia Pacific. Journal of Banking \& Finance 38, 64-77.

Kim, Y. D., Anderson, D. R., Amburgey, T. L. and Hickman, J. C. 1995. The use of event history analysis to examine insurer insolvencies. Journal of Risk and Insurance 94-110.

Kozak, S. 2011. Determinants of profitability of non-life insurance companies in Poland during integration with the European financial system. Electronic Journal of Polish Agricultural Universities 14 (1): 1-9.

Laeven, L. and Levine, R. 2009. Bank governance, regulation and risk taking. Journal of financial economics 93 (2): 259-275.

Mahlberg, B. and Url, T. 2003. Effects of the single market on the Austrian insurance industry. Empirical Economics 28 (4): 813-838.

Majumdar, S. K. 1997. The impact of size and age on firmlevel performance: some evidence from India. Review of industrial organization 12 (2): 231-241.

Medved, D. and Kavčič, S. 2012. An Empirical Study of Efficiency in Croatia and Slovenia Insurance Markets. Economic research-Ekonomska istraživanja 25 (1): 87-98.

O'Sullivan, N. and Diacon, S. R. 2003. Board composition and performance in life insurance companies. British Journal of Management 14 (2): 115-129.

Pasiouras, F. and Gaganis, C. 2013. Regulations and soundness of insurance firms: International evidence. Journal of Business Research 66 (5): 632-642.
Rubio-Misas, M. and Fernández-Moreno, M. 2017. Solvency surveillance and financial crisis: evidence from the Spanish insurance industry. Spanish Journal of Finance and Accounting/Revista Española de Financiación y Contabilidad 46 (3): 272-297.

Schaeck, K. and Cihák, M. 2014. Competition, efficiency, and stability in banking. Financial Management 43 (1): 215-241.

Shim, J. 2011. Mergers \& acquisitions, diversification and performance in the US property-liability insurance industry. Journal of Financial Services Research 39 (3): 119-144.

Shim, J. 2015. An investigation of market concentration and financial stability in property-liability insurance industry. The Journal of Risk and Insurance 84 (2): 567-597.

Shiu, Y. 2004. Determinants of United Kingdom general insurance company performance. British Actuarial Journal 10 (5): 1079-1110.

Stiroh, K. J. and Rumble, A. 2006. The dark side of diversification: The case of US financial holding companies. Journal of Banking \& Finance 30 (8): 2131-2161.

Šebjan, U. and Tominc, P. 2015. Conceptual model of relationships among customer perceptions of components of insurance companies. South East European Journal of Economics and Business 10 (1): 32-44.

Van Leuvensteijn, M., Bikker, J. A., Van Rixtel, A. A. and Sørensen, C. K. 2011. A new approach to measuring competition in the loan markets of the euro area. Applied Economics 43 (23): 3155-3167.

Wang, J. L., Jeng, V. and Peng, J. L. 2007. The impact of corporate governance structure on the efficiency performance of insurance companies in Taiwan. The Geneva Papers on Risk and Insurance-Issues and Practice 32 (2): 264-282.

Weiss, M. A. and Choi, B. P. (2008). State regulation and the structure, conduct, efficiency and performance of US auto insurers. Journal of Banking \& Finance 32 (1): 134-156. 